\title{
FACTORS RELATED TO MALNUTRITION EVENTS IN UNDER-FIVE CHILDREN IN KABUKARUDI VILLAGE, EAST NUSA TENGGARA
}

\author{
Nepriana Buta Rade1), Theresia Puspitawati2), Jati Untari²) \\ 1)Non-governmental organization Sumba foundation \\ 2)Public Health Study Program, Faculty of Health Sciences, Universitas Respati Yogyakarta
}

\begin{abstract}
Background: Malnutrition has become an urgent global health problem. Millions of people are killed or disabled every year due to insufficient nutrition. Indirectly influenced by upbringing, food availability, socio-economic, cultural, and environmental factors. Based on the regency, the highest percentage is in West Sumba (12.20\%). This study aimed to find out the factors related to malnutrition events in under-five children in Kabukarudi village, East Nusa Tenggara.

Subjects and Method: This was a cross sectional study conducted in Kabukarudi Village, Lamboya District, West Sumba Regency, East Nusa Tenggara. A sample of 99 was selected by purporsive sampling. The data was analyzed by chi square.

Results: Relationship between knowledge level $(p=0.047)$, type of foodstuff $(p<0.001)$, and infectious diseases $(\mathrm{p}<0.001)$ it was statistically significant.

Conclusion: Malnutrition events in under-five children is associated with knowledge level about nutrition, type of food consumed and infectious disease.

Keywords: malnutrition, knowledge, food variant, infection desease

Correspondence:

Theresia Puspitawati. Public Health Study Program, Faculty of Health Sciences, Universitas Respati Yogyakarta. Jl. Laksda Adisucipto KM.6,3, Ambarukmo, Caturtunggal, Sleman distric, Yogyakarta 55281 E-mail: thpuspitawati@gmail.com. Mobile: +628122719110.
\end{abstract}

The $7^{\text {th }}$ International Conference on Public Health

Solo, Indonesia, November 18-19, 2020 | 66

https://doi.org/10.26911/the7thicph.01.21 